\title{
Emotion Expression when Teaching with Creative Movement
}

\author{
Simona Prosen ', Vesna Geršak', Gregor Geršak ${ }^{2}$ and Helena Smrtnik Vitulić \\ 'University of Ljubljana Faculty of Education, \\ ${ }^{2}$ University of Ljubljana Faculty of Electrical Engineering
}

\section{Abstract}

The study focuses on students' emotion expression during geometry teaching including creative movement (experimental group or EG) and without it (control group or CG). The sample $(N=104)$ was made up of primary school (second-grade) students: 66 were assigned to the EG and 38 to the CG. Of these, 12 students from the EG and 8 from the CG were randomly selected for observation of emotion: type, intensity, triggering situation, and response of others. For the observed students, the intensity of emotion expression was also measured by the facial expression recognition software FaceReader. All of the students self-assessed their contentedness with the teaching. The students in the EG and the CG expressed various emotions, with joy being the most prevalent, followed by anger. The most frequent situations triggering joy were activities in the EG and the CG. The intensity of joy was higher in the EG than in the $C G$ when assessed by observation, but there was no significant difference when assessed by FaceReader. The intensity of anger expression was at a similar level in both groups. Both students and teachers responded to students' joy expression, but only the students responded to anger expression in the EG and the CG. The students in both groups expressed a high level of contentedness with the teaching.

Key words: creative movement; emotion expression; intensity of emotions; students; teaching method

\section{Introduction}

Emotions are relevant for the quality of group interactions and atmosphere (Meyer \& Turner, 2007; Prosen et al., 2013), but they also impact a person's motivation, memory, and creativity (Fredrickson, 2008), and therefore represent an important topic of study within the school context. 
Unfortunately, emotions are insufficiently represented in educational research, but some changes have taken place in the area recently (Bognar \& Dubovicki, 2012; Bognar \& Kragulj, 2010; Dubovicki, 2014; Suzić, 2008). Many factors influence the emergence of emotions, one of which may be teaching method (Geršak, 2016). In our study, we therefore focus on the expression of emotions among children in middle childhood (children in Slovenia enter school at the age of six, which is at the beginning of this developmental period), comparing the use of the teaching method of creative movement in the classroom with a "classic" teaching method (without creative movement). In the continuation, emotions will be defined regarding certain important criteria, situations that trigger emotions will be outlined, and emotion expression will be considered. The teaching method of creative movement will then be presented, as it may influence the emotion expression process in the classroom.

Emotions include specific sequences of physiological changes, cognitive processing, verbal and non-verbal expression, and behaviour or action tendencies (Oatley \& Jenkins, 1996) that emerge in response to a subjectively important event (Lazarus, 1991). Emotions can be categorized regarding their valence (Prosen \& Smrtnik Vitulić, 2014): pleasant emotions (e.g. joy, pride) emerge as a response to the achievement of a subjectively important goal, while unpleasant emotions (e.g. anger, fear) emerge when an important goal is not achieved (e.g. Fredrickson, 2008; Oatley \& Jenkins, 1996). Emotions may also vary in terms of their intensity, depending on the importance of the goal. Another categorization divides emotions according to their complexity. Basic emotions (e.g. joy, anger, fear, surprise) appear early in the infant's development, include specific circuits of brain activity, and have a typical adjustment function and facial expressions (Ekman \& Davidson 1994). On the other hand, complex emotions (e.g. shame, disappointment) emerge later in development and have less typical expression (Papalia et al., 2009). Consequently, basic emotions can be recognized more easily than complex ones.

As the present article focuses, inter alia, on situations that trigger emotion expression in students, situations relevant to them will be presented. Emotions emerge when a person perceives a situation as subjectively important (Lazarus, 1991). What is perceived as important, however, differs according to the person's age, as different developmental periods are accompanied by different personal preferences, goals, and expectations (Prosen \& Smrtnik Vitulić, 2017; Saarni, 1999; Sutton, 2007). Children in middle childhood are very much concerned with their competence, as being industrious or inferior represents a principal conflict of this developmental period (Erikson, 1980/2014). Bearing this in mind, being successful or unsuccessful, especially at school, may be a source of different emotions. When a student performs well in a school activity, for example, he or she may feel joy, as he or she perceives this as the accomplishment of an important goal (Oatley \& Jenkins, 1996). On the other hand, when a student fails to accomplish a particular school task and perceives him or herself as being hindered while trying, he or she may feel anger (Oatley \& 
Jenkins, 1996). If, in a similar situation, a student perceives such non-achievement as below his or her expectation, disappointment may occur (Saarni, 1999), or, if a student perceives him or herself as being exposed in an unpleasant way in front of the other children or the teacher, shame may emerge (Harter \& Whitesell, 1991). Another very important topic in this developmental period is relationships with peers, as their influence starts to grow (Kail \& Cavanaugh, 2013). Therefore, it is not surprising that social relationships represent a source of various emotions. If a student feels accepted in a group of peers, for example, he or she may often experience joy. On the other hand, when others do not act according to the student's expectations, he or she may be angry (Oatley \& Jenkins, 1996), and so forth.

Various studies of emotions try to explore certain aspects of the emotion process, such as emotion expression (Harris, 1996; Prosen \& Smrtnik Vitulić, 2017), which is the focus of the present study. A variety of intrinsic and extrinsic factors contribute to emotion expression (e.g. Thompson, 2011). The maturation of the brain and temperamental characteristics are among intrinsic factors (Derryberry \& Rothbart, 1988; Siegel, 1999), while family environment, peer relationships, and cultural context are among extrinsic factors important for emotion expression (Eisenberg et al., 2009; Fox \& Calkins, 2003; Thompson \& Meyer, 2009; Thompson, 2011). In middle childhood, children are still learning how to express emotions in an appropriate way (Papalia et al., 2009). Important sources of this learning may include the recognition of emotional processes in oneself and others, as well as the modelling of emotion expression by others. The body can play a role in the recognition of emotions in oneself and others (Damasio, 1999; Duclos et al., 1989), while peers may play a significant part in modelling emotion expression (Parker \& Asher, 1987, as cited in Fox \& Calkins, 2003), especially as their importance grows in middle childhood (Kail \& Cavanaugh, 2013). In addition, the reactions of peers to the individual's emotions may contribute to their further overt expression or their suppression, as students of this age are often capable of hiding emotions in certain social situations. The teacher is also an important figure within the school context: her or his modelling of emotions and reaction to students' emotion expression provides important guidance for students' behaviour (Thom, 2010).

Among the aforementioned extrinsic factors, the school environment represents an important context for shaping emotion expression (Sutton, 2007), including the teaching method used in the classroom (e.g. Geršak, 2016). One of the teaching methods that may be connected to emotion expression is creative movement. This is a holistic teaching and learning method whereby students activate all of their senses and use movement to express, form, and create various educational content through their bodies (Geršak, 2016; Kroflič, 2002). For example, students may use their bodies to show geometric shapes or solids, such as a square or cube, and learn to differentiate between them. This method is based on different concepts that encourage an awareness of inner experience through movement (Feldenkrais, 1990) 
or analyse various elements of movement (Laban, 1975). Creative movement is also based on the concept of embodied cognition that emphasizes the interdependence of body and mind, postulating that movement influences our cognition and vice versa (Davidson, 2004; Osgood-Campbell, 2015). "By creating a rich contextual environment, kinesthetic learning constructs memories related to time, place and emotions ... Students activate and integrate physical, emotional, and cognitive responses to what they are learning, making learning more meaningful" (Griss, 2013). However, given that the processes of cognitive, emotional, social, and physical development are intertwined, cognition is not the only process that is influenced by movement. Emotions are inextricable from the body, as their neural processing includes body markers (Damasio, 1998). In addition, the recognition of non-verbal means of emotion expression takes place as children look to each other for cues and copy each other's movement tendencies.

As shown by some studies including school children and adolescents (e.g. Geršak \& Geršak, 2016; Griss, 2013; Kroflič, 2002), creative movement encourages creativity, motor and cognitive skills, and pleasant emotional and social experiences, which leads to increased cooperation between students and motivation for learning. As creative movement also encourages body awareness, it may contribute to children's emotional development and developing social cognition (Frith \& Frith, 2007). However, the majority of previous studies on creative movement were designed non-experimentally, exploring only children or adolescents with whom creative movement was employed. Regarding emotions, the data was gathered using short questionnaires or less structured teacher reflections on children concerning their general emotional experience during creative movement employment. In the present study, we therefore tried to rectify these limitations. We compare a teaching process that employs creative movement with one in which creative movement is absent, in order to establish (1) which emotions are expressed by children in middle childhood, (2) the intensity of the two most frequently observed emotions, (3) the situations that trigger these two emotions, and (4) the reactions of the teacher and the other students to these emotions. Additionally, we are interested in (5) the students' level of contentedness with the teaching process.

\section{Methods}

\section{Sample}

The sample comprised 104 second-grade students, half of whom were boys $(M=$ 7.5 years, $\mathrm{SD}=0.47$ ), from five primary schools in Slovenia: 66 attended classes taught with creative movement (three experimental group classes - EC) and 38 attended classes in which creative movement was not employed (two control group classes $\mathrm{CG}$ ). There was initially an equal number of $\mathrm{EC}$ and CG group classes; however, due to subsequent changes in the teaching plan after its first execution, the results from one of the CG classes were excluded from further analysis. Four children in each class (12 
in the EG and 8 in the CG, half of them boys) were randomly chosen for observation of their emotion expression.

\section{Instruments}

The children who were chosen for observation were assessed using the Emotion Observation Scheme (Prosen \& Smrtnik Vitulić, 2016) (Appendix 1), which includes the type of emotion displayed and the intensity of expression (on a 5-point Likert-type scale, from 1 - very weak to 5 - very strong), as well as a description of the situation, the verbal and non-verbal expression of the emotion, and the responses of the teacher and the other students involved in the interaction. Emotions were recorded twice per meeting, for ten minutes each time. Each emotion was recorded as it occurred, in chronological order. If a certain emotion appeared more than once, it was recorded each time. The observers participated in a special training course held by the authors of the study, during which they were trained to use the described scheme to observe and record the children's emotion expression in the classroom.

In addition to the observations described above, the facial expression recognition software FaceReader (by Noldus, The Netherlands) was used to measure the intensity of the emotions in the observed children. By detecting facial expressions, FaceReader can classify them into the following categories of basic emotions: joy, sadness, anger, surprise, fear, and disgust. In addition, FaceReader recognizes neutral facial expressions. The software's ability to detect emotions has been shown to be comparable to that of a human (Lewinski et al., 2014).

All of the children participating in the study also self-assessed themselves on the Contentedness Scale, which includes five pictures of faces/smileys (from 1 - very discontent to 5 - very content). The children marked the face that best described them during the teaching process.

\section{Procedure}

The article presents results gathered within a broader study on the link between the creative movement teaching method and various areas of development, e.g. emotional, social and motor development. We first designed the plans for the lessons including creative movement and those without creative movement, which consisted of six lessons (three times for two lessons) of mathematics instruction (geometry: lines and points, shapes and solids, symmetry). The chosen topics had not yet been taught in class. For example, when the children were taught about geometric shapes and solids in the EG they were divided into smaller groups that were asked to create and present a selected geometric shape using their body, while the other students guessed which geometric shape was being presented. In the CG, each child received an envelope containing cards with different geometric shapes drawn. The teacher then named the shapes and the students raised the appropriate card showing the named shape.

The lesson content was based on a range of literature and on experience acquired by four university students included in the study, as well as on suggestions from second- 
grade teachers, artists/choreographers, and the authors of the study. Creative movement employment was based on the work of various authors (e.g. Griss, 2013; Kroflič, 2002; Minton, 2008; Overby, 2014). In addition, instruments for the measurement and observation of various developmental areas were selected. We then contacted schools that were willing to participate in the study and obtained parental consent for the children's inclusion. The students visited all of the classes in order to get to know the children prior the experiment. Following this first visit, they conducted the lessons in each class for one week. The children in the CG were taught using the classic audio and visual ex-cathedra method, including several didactic games (e.g. bingo) in which the students individually solved problems that usually required convergent answers, while the children in the EG were taught the same topics by means of the creative movement method, including a lot of body activities, searching for divergent solutions to problems, and working in pairs or small groups. During these lessons, the contentedness scale (for all students) and observation of emotion expression (for selected students) were employed. In addition, the selected students' faces were filmed using an $\mathrm{HD}$ video camera in order to enable post-processing with the facial analysis software FaceReader.

\section{Results}

In the Results section, a comparison of the emotions expressed by the selected students in the middle childhood study will be presented regarding the employment or non-employment of the creative movement method during teaching. The intensity of the two most frequently observed emotions, the situations triggering them, and the reactions of the teachers and the other students to these emotions will also be described. In addition, the intensity of these two emotions as measured by FaceReader will also be presented. Finally, the level of student contentedness with the teaching process will be analyzed, based on feedback from all of the participating students.

\section{Type, frequency and intensity of the students' emotions}

The results (Table 1) show that the observed students in the EG and the CG expressed various emotions in the classroom, and that these emotions differed considerably in their frequency.

The pleasant emotion of joy was the most frequently observed emotion in both groups, being noted 11.6 times per child in the EG and 10.4 times in the CG. The expression of joy represents $93.3 \%$ of all of the occurrences of emotion expression in the EG and $85.6 \%$ in the CG; the difference between the groups is not significant. The next most frequently observed emotion in both groups - although considerably less frequently noted than joy - was the unpleasant emotion of anger, representing $5.3 \%$ of the expressed emotions in the EG and $8.2 \%$ in the CG; again the difference is not significant. Anger was observed 0.7 times per child in the EG and 1 time in the CG. Other unpleasant emotions (disappointment, shame, fear and negative surprise) 
were expressed less frequently in both groups. The overall ratio between pleasant and unpleasant emotions was approximately 14:1 in the EG and 6:1 in the CG. Almost all of the observed emotions are basic emotions (joy, anger, fear, and negative surprise), with the exception of two complex emotions: disappointment and shame.

Table 1

Type and frequency of the students' emotions in the experimental and control groups, and differences in the two most frequently expressed emotions

\begin{tabular}{lcccccc}
\hline & EG & & CG & M & Sum & Results \\
\hline Joy & $f$ & $M$ & $f$ & & & Chi $(1)=0.63, p>0.05$ \\
Anger & $139(93.3 \%)$ & 11.6 & $83(85.6 \%)$ & 10.4 & 222 & Chi $(1)=0.54, p>0.05$ \\
Disappointment & $8(5.3 \%)$ & 0.7 & $8(8.2 \%)$ & 1.0 & 16 & \\
Shame & $0(0.0 \%)$ & & $4(4.2 \%)$ & & 4 & \\
Fear & $1(0.7 \%)$ & & $1(1.0 \%)$ & & 2 & \\
Negative surprise & $1(0.7 \%)$ & & $0(0.0 \%)$ & & 1 & \\
Total & $0(0.0 \%)$ & $1(1.0 \%)$ & & 1 & \\
\hline
\end{tabular}

Note. $N$ in the $\mathrm{EG}=12, N$ in the $\mathrm{CG}=8$

Next, the intensity of the two most frequently expressed emotions was calculated. Measured on a 5-point scale, the intensity of joy was slightly below the middle in the $\mathrm{EG}(\mathrm{M}=2.70, \mathrm{SD}=1.02)$ and even lower in the $\mathrm{CG}(\mathrm{M}=2.33, \mathrm{SD}=1.02)$. There was a significant difference in the intensity of joy expression between the EG and the CG ( $\mathrm{t}$-test for independent samples: $\mathrm{t}=2.54, \mathrm{df}=221, \mathrm{p}=0.01$ ). The intensity of anger was below the middle in the $\mathrm{EG}(\mathrm{M}=2.50, \mathrm{SD}=0.93)$ and slightly higher in the $\mathrm{CG}$ $(\mathrm{M}=2.75, \mathrm{SD}=0.89)$, but the difference between the groups was not significant ( $\mathrm{t}$-test for independent samples: $\mathrm{t}=-0.55, \mathrm{df}=15, \mathrm{p}=0.59$ ).

In addition, the intensity of joy and anger as measured by FaceReader software was analysed. The intensity of joy (in arbitrary units) was compared in the EG and the CG $(\mathrm{MEG}=0.26, \mathrm{SDEG}=0.13$; $\mathrm{MCG}=0.25, \mathrm{SDCG}=0.07)$ with no statistically significant difference confirmed ( $\mathrm{t}$-test for independent samples: $\mathrm{t}=0.29, \mathrm{df}=26, \mathrm{p}$ $=0.77$ ). Similarly, the intensity of anger was compared in the EG and the CG (MEG $=0.01, \mathrm{SDEG}=0.01 ; \mathrm{MCG}=0.01, \mathrm{SDCG}=0.00$ ), with no statistically significant difference being detected ( $\mathrm{t}$-test for independent samples: $\mathrm{t}=0.91, \mathrm{df}=26, \mathrm{p}=0.37$ ).

\section{Situations that trigger joy and anger}

The descriptions of the situations that triggered emotions in the students were reviewed by all of the authors of the study and organized into several response categories for each observed emotion. Each description was then placed into one of these categories. The categories of joy and anger (as the two most frequently observed emotions) are presented in Table 2. 
Table 2

The frequency and percentage of triggering situations of joy and anger in the $E G$ and the $C G$

\begin{tabular}{lcclcc}
\hline Joy & EG (\%) & CG (\%) & \multicolumn{1}{c}{ Anger } & EG & CG \\
\hline Activity with/without & & & Activity with/without & & \\
movement & $76(54.7 \%)$ & $45(54.3 \%)$ & movement & 4 & 0 \\
Social interaction & $25(18.0 \%)$ & $9(10.8 \%)$ & Waiting & 0 & 5 \\
Knowledge and ideas & $13(9.4 \%)$ & $12(14.5 \%)$ & Not knowing & 2 & 0 \\
Presentation & $10(7.2 \%)$ & $1(1.2 \%)$ & Not acknowledged & 0 & 2 \\
Funny events & $7(5.0 \%)$ & $4(4.8 \%)$ & Someone's & & \\
& $2(1.4 \%)$ & $7(8.4 \%)$ & & 2 & 1 \\
Victory & $4(2.9 \%)$ & $1(1.2 \%)$ & & & \\
Leadership & $2(1.4 \%)$ & $4(4.8 \%)$ & & & \\
Other & $139(100 \%)$ & $83(100 \%)$ & $\sum$ anger & & 8 \\
$\Sigma$ joy & & & & \\
\hline
\end{tabular}

Note. $N$ in the $\mathrm{EG}=12, N$ in the $\mathrm{CG}=8$

The situations that triggered joy included activities during movement in the EG and during verbal activities in the CG (54.7\% in the EG and 54.3\% in the CG, e.g., a student plays the role of a statue in the EG/participates in bingo in the CG), social interaction (18.0\% in the EG and 10.8\% in the CG, e.g., a student finds a pair to work with), knowledge and ideas (9.4\% in the EG and $14.5 \%$ in the CG, e.g., a student talks about how to represent symmetry with his classmate), presentation ( $7.2 \%$ in the EG and $1.2 \%$ in the CG, e.g., a student presents a line with her body in front of the class), funny events (5.0\% in the EG and $4.8 \%$ in the CG, e.g., a student tells a joke), victory ( $1.4 \%$ in the EG and $8.4 \%$ in the CG, e.g., a student wins in bingo), leadership (2.9\% in the EG and 1.2\% in the CG, e.g., a student leads the group when exploring their ideas), and other (1.4\% in the EG and $4.8 \%$ in the CG, e.g., a student plays with his notebook).

The situations that triggered students' anger were activities (during movement in the EG) (4 times, only in the EG, e.g., a student participates in a group that makes geometric shapes with rubber bands and they cannot agree on a solution), waiting (5 times, only in the CG, e.g., a student wants to start the activity), not knowing (twice only in the CG, e.g., a student does not know how to find the required geometric shape), not being acknowledged (twice only in the EG, e.g., a student's classmate does not listen to his idea), and someone's inappropriate behaviour (twice in the EG and once in the CG, e.g., a classmate hands him the wrong card).

\section{Reactions of the other students and the teacher to joy and anger}

In Table 3, the frequencies of various reactions of the other students and the teacher to joy and anger expression are presented.

Observations of the students' responses to joy expression included 55 responses in the EG and 8 in the CG. These responses were distributed into three categories: laughing with (43 times in the EG and 6 times in the CG, e.g., a classmate laughs with a student); following (11 times in the EG and twice in the CG, e.g., a classmate follows 
a student's instructions); praise (once in the EG, e.g., a classmate encourages a student's work). With regard to the teachers, 2 responses were observed in the EG and 5 in the CG: praise (once in the EG and 3 times in the CG, e.g., a teacher says Bravo! as she watches a student's presentation), call on (once in the EG and once in the CG, e.g., a teacher calls on a student to give the answer), and laughing with (once in the CG, e.g., a teacher laughs with a student).

Table 3

Reactions of the other students and the teacher to joy and anger expression

\begin{tabular}{|c|c|c|c|c|c|}
\hline Joy & EG & CG & Anger & EG & CG \\
\hline \multicolumn{6}{|l|}{ Students } \\
\hline Laughing with & 43 & 6 & Acknowledgement & 3 & 0 \\
\hline Following & 11 & 2 & Chaos & 2 & 1 \\
\hline \multirow[t]{2}{*}{ Praise } & 1 & 0 & Clarification & 1 & 0 \\
\hline & & & Laughing at & 1 & 0 \\
\hline$\Sigma$ students' response & 55 & 8 & $\Sigma$ students' response & 7 & 1 \\
\hline \multicolumn{6}{|l|}{ Teacher } \\
\hline Praise & 1 & 3 & & & \\
\hline Called on & 1 & 1 & & & \\
\hline Laughing with & 0 & 1 & & & \\
\hline$\sum$ teacher's response & 2 & 5 & & & \\
\hline$\Sigma$ joy & 57 & 13 & $\sum$ anger & 7 & 1 \\
\hline
\end{tabular}

Note. $\mathrm{N}$ in the $\mathrm{EG}=12, \mathrm{~N}$ in the $\mathrm{CG}=8$

The observations of students' responses to anger expression included 7 responses in the EG and 1 in the CG. These responses were categorized into: acknowledgement (3 times in the EG, e.g., a classmate changes her position), chaos (twice in the EG and once in the CG, e.g., a classmate looks at the student in bewilderment); clarification (once in the EG, e.g., a classmate explains why he does not want to present in such way), and laughing at (once in the EG, e.g., two classmates laugh at a student).

\section{Contentedness with the teaching process}

Finally, all of the students self-assessed their level of contentedness with the teaching process. The results are presented in Table 4.

Table 4

Students' level of contentedness with the teaching process

\begin{tabular}{ccccccc}
\hline & $\mathrm{N}$ & $\mathrm{M}$ & $\mathrm{SD}$ & $\mathrm{t}$ & $\mathrm{df}$ & $\mathrm{p}$ \\
\hline EG & 66 & 4.32 & 0.89 & -1.68 & 99.95 & 0.10 \\
CG & 38 & 4.56 & 0.59 & & & \\
\hline
\end{tabular}

Note $\mathrm{M}=$ mean, $\mathrm{SD}=$ standard deviation

The students in both the EG and the CG expressed a high level of contentedness with the teaching process, and there are no statistically significant differences between the groups $(\mathrm{t}=-1.68, \mathrm{df}=99.95, \mathrm{p}=0.10)$. 


\section{Discussion}

Emotions are an important topic of study within the school context (e.g. Prosen et al., 2013). Various factors contribute to their emergence, one of which may be the teaching method (Geršak, 2016). The present study focuses on the use of creative movement: a holistic teaching and learning method whereby students use movement to access diverse educational content (Kroflič, 2002; Geršak, 2016). The study compares the emotion expression of students in the classroom during lessons employing creative movement and lessons without creative movement. The teaching process was executed in second-grade classes of primary schools during mathematics (geometry) instruction. The participating students were aged around seven years, thus placing them in middle childhood. This notion is important when analysing student emotion expression, as each developmental period has its own specific characteristics, including in the area of emotion (Kail \& Cavanaugh, 2013).

The observed students in both the EG and the CG expressed various emotions in the classroom, indicating that school situations are perceived by students as subjectively important in middle childhood, which is a prerequisite for the emergence of emotions (e.g. Lazarus, 1991; Saarni, 1999). Among all of the expressed emotions in both groups, the pleasant emotion of joy prevails, followed by the unpleasant emotions of anger, disappointment, shame, fear, and negative surprise. In the EG, the ratio between pleasant and unpleasant emotions is approximately $14: 1$, while in the CG it is 6:1. Fredrickson (2008) recommends that this ratio should favour pleasant emotions, as unpleasant emotions impact emotional balance more strongly than pleasant emotions. The ratios in our study are in line with the above recommendation in both groups, but especially in the EG. Such results are encouraging, as pleasant emotions may contribute to a pleasant atmosphere, supporting students' competence and autonomy (Meyer \& Turner, 2007). The teaching process was a source of joy regardless of the teaching method used, but the results reflect the more playful nature of the creative movement method.

Almost all of the observed emotions in both groups are basic emotions (joy, anger, fear and negative surprise): they appear early in development, they include specific circuits of brain activity, and they have a typical adjustment function and facial expressions (Ekman \& Davidson, 1994). Only two complex emotions were recorded in the observed students: disappointment and shame. As complex emotions emerge later in development and have less typical expression (Papalia et al., 2009), they are more difficult to recognize than basic ones. This may partly explain the prevalence of basic emotions in our results.

The further analysis focused on the two most frequently expressed emotions: joy and anger. As mentioned above, the most prevalent emotion - statistically equally represented in both groups (93.3\% in the EG and in $85.6 \%$ in the CG) - was joy that occurs upon the perceived accomplishment of an important goal (Oatley \& 
Jenkins, 1996). Within the school context, the accomplishment of a school task may represent such a goal. The intensity of the expressed joy was moderate in the EG and significantly lower in the CG. It may be that the students in the EG perceived joy-eliciting situations as being more important during creative movement, thus contributing to a higher intensity of joy than in the CG, where creative movement was absent from the lessons plans. Another explanation could be that the students observed during creative movement were more relaxed and spontaneous, resulting in a more open expression of joy, which was therefore recognized as more intense. However, when the intensity of joy was measured in a different, technically supported way using FaceReader software, there were no statistical differences between the EG and the CG. This may indicate differences between assessments when performed by a person or by a machine, even though the software's ability to detect emotions has been shown to be comparable to that of a human being (Lewinski et al., 2014). The observers usually took into account a more holistic picture of the occurrence of emotion (joy) - in addition to facial expression, their observations may also have been based on gestures, verbal expression, etc. - and this may have contributed to their different assessment of the intensity of joy. Furthermore, methods of automatic facial recognition of emotions are limited due to technological sources of error (e.g. the matureness of the built-in mathematical algorithm for facial expression recognition, environmental conditions such as the lighting in the classroom, the length of the recording interval), even though they are controlled and minimized. Additionally, an awareness of being observed may have had an impact on the children's facial expressions, although the constant presence of a camera was not unsettling for them. The question of more objective assessment therefore remains open, which is important given the recent advances in facial vision systems for monitoring emotion expression. In our case, adding such measurement enabled a comparison of gathering data on emotions via different methods, opening up the possibility of evaluating the methods themselves: human vs. computer observation.

The discussion on the measurement of emotions may even be developed further taking into consideration Michell's (2009) critical view on the quantification of psychological phenomena such as emotions. This is, of course, a valid dilemma that could be addressed in future research including qualitative data (e.g. interviews with students). However, the quantification of emotions may also contribute to the understanding of this elusive phenomenon.

The situations that triggered joy mainly included activities during movement in the EG and verbal activities in the CG, followed by social interaction, and knowledge and ideas. Joy was occasionally triggered by presentation, funny events and victory, and seldom by leadership and other situations. These joy-eliciting situations can be viewed from a developmental perspective, as competence is a particularly important issue among children in middle childhood (Erikson, 1980/2014). Therefore, the observation that children expressed joy in situations where they actively pursued 
their school goals, showed their knowledge and ideas, or presented their topics is not surprising. Relationships with peers are another important source of emotions in middle childhood (Kail \& Cavanaugh, 2013), so situations including social interaction are quite frequently represented as joy-eliciting. When examining joyeliciting situations in the EG and the CG, it can be observed that situations including social interaction and presentation were somewhat more highly represented in the EG. It may be that when the creative movement method was employed during teaching the children were more frequently encouraged to work in groups and find solutions to school tasks. On the other hand, situations including children's knowledge, ideas, and victory were slightly more highly represented in the CG, which could be because the teaching process without creative movement included more competition-oriented tasks.

The responses of the other students and the teachers to joy expression mostly included laughing with and following the given instructions, and rarely involved praise and call on. Furthermore, the reactions of the other students were much more frequent than those of the teacher. The process of learning to express emotion is still ongoing in middle childhood (Denham et al., 2003), so the recognition and modelling of emotion expression by others, including peers and the teacher, is important (Parker \& Asher, 1987, as cited in Fox \& Calkins, 2003; Thom, 2010). The responses of students and teachers to joy expression encourage such expression, helping the child know that his or her emotions are being seen and accepted, and contributing to an emotionally safe classroom environment.

The second most prevalent emotion - albeit far less frequently expressed and statistically equally represented in the EG and the CG - was anger (5.3\% in the EG and in $8.2 \%$ in the CG). A person may feel angry when his or her plan to achieve an important goal is frustrated (Oatley \& Jenkins, 1996). In the school context, a student who fails to accomplish a certain task due to being hindered while trying may feel anger (Oatley \& Jenkins, 1996). In the present study, the intensity of anger was moderate in both groups, with no significant difference between them. Nor did the measurement of anger intensity using FaceReader find any differences between the groups.

The situations that triggered anger were activity not being acknowledged in the EG, and waiting and not knowing in the CG, while the inappropriate behaviour of other students was a trigger in both groups. All of these situations fit into the aforementioned definition of anger in the school context, as they all involve the child feeling hindered. However, it is interesting that anger was more frequently expressed during activities when the creative movement method was employed. This may be due to a more actively shaped teaching process that included a lot of group work, possibly resulting in the activities of individual students not being acknowledged. On the other hand, there may have been more waiting when the teaching process did not involve the use of creative movement, as the lessons were 
conducted using more individualized work. Furthermore, the lack of knowledge of individual students may have been more overtly exposed, leading to their anger.

Only the other students (and not the teacher) responded to anger expression by acknowledging their classmate's demands, chaos, clarification, and laughing at their classmate. Interestingly, the majority of these reactions were observed in the EG. Acknowledgement and clarification may represent a more functional response to anger, as they can lead to finding a common solution. On the other hand, laughing at the angry person in particular may aggravate the situation. Besides peers, the teacher's reaction to students' emotion expression provides important guidance for their behaviour (Thom, 2010); therefore, teachers' lack of response to anger may need to be explored further.

Finally, all of the students self-assessed their level of contentedness with the teaching process. The students in both the EG and the CG expressed a high level of contentment with the classes, and there were no significant differences between the two groups. This is in accordance with the previously presented results showing that joy was the most prevalent observed emotion in the selected students during lessons. The students obviously enjoyed the teaching process in both teaching situations, with and without the employment of creative movement, perhaps indicating the quality of both teaching performances.

\section{Conclusions}

The present study focused on students' emotion expression, comparing it within two teaching contexts: with and without the employment of the creative movement method. The observed children in the EG and the CG expressed various emotions. The only pleasant emotion expressed was joy, which was also by far the most prevalent of all of the emotions expressed. In terms of frequency, joy was followed by the unpleasant emotion of anger, while the emotions of disappointment, shame, fear, and negative surprise were rarely observed. Further analysis focused only on the two most frequent emotions, joy and anger. The intensity of joy, as assessed by the observers, was significantly lower in the CG than the EG. However, when assessed by FaceReader software, no significant difference was found, thus raising the question of measurement characteristics such as objectivity. No significant difference between the EG and the CG in the intensity of anger was confirmed by either assessment method.

The situations that most frequently triggered joy included activities during movement in the EG and verbal activities in the CG. Other situations were also joy-eliciting, such as social interaction, and showing knowledge and ideas. In the EG, anger was most frequently expressed in situations in which the activity of an individual child was not acknowledged, while in the CG situations evoking anger included waiting and not knowing. The prevalence of activity as an emotion-eliciting situation may be understood in the context of the characteristics of middle childhood, which 
include the issue of the child's competence (Erikson, 1980/2014). The aforementioned prevalence of activities as emotion-eliciting may also be indicative of the importance of the chosen teaching method. In both groups, the other students and the teachers responded to joy expression mostly by laughing with their classmate/student and following his or her given instructions. However, only the other students (not the teacher) responded to anger expression by acknowledging their classmate's demands, chaos, clarification, and laughing at their classmate. The students in both the EG and the CG expressed a high level of contentment with the teaching process.

It can be concluded that the students experienced a similar level of contentment with and without creative movement, and that both methods elicited mostly the pleasant emotion of joy and evoked other unpleasant emotions far less frequently. The intensity of the observed joy was, however, higher when creative movement was employed. The situations triggering the emotions were also quite similar in the two groups, although some differences did emerge (e.g. social interaction triggered joy more frequently in the EG than in the CG). The responses of the other students and the teacher were similar for joy, but the teacher's response to anger was lacking in the EG and the CG. This may be indicative of the fact that both methods are well accepted by students, and both can be used in the classroom to encourage the quality of the group atmosphere.

The results obtained have many implications for teachers and other professionals working in an educational setting. In educational programs for teachers, it is crucial to encourage an awareness and understanding of emotions, as well as an awareness of the importance of the use of a particular teaching method. It is vital for teachers to be familiar with teaching methods that encourage a group atmosphere, the creative movement method being among them. This kind of knowledge may support teachers in starting to use creative movement in the classroom, despite possibly representing a significant shift in the teacher's conception of teaching methods.

The present study is one of the first studies to combine two important areas of research: emotions in the school context, and creative movement as an emerging way of teaching. Furthermore, it is among the rare studies that employ experimental design to explore emotions during the use of creative movement. This is achieved by combining and comparing several assessment tools and sources: human observation and automated computer observation (by means of FaceReader software), and the self-assessment of the participants themselves. These strengths of the study come along with its shortcomings, including the small number of students who were observed in greater detail. Furthermore, the teaching process was very rich in both the EG and the CG (well prepared, including creative tasks), and as such it may not entirely represent the everyday process in the classroom. This probably contributed to the similar results of both teaching methods. Therefore, further research should be conducted taking into account these notions. In addition, links between the teaching method and other areas of the child's functioning could be explored, such as social interaction or creativity. Creative movement itself could also be explored 
in greater detail, possibly using Laban's movement analysis, focusing on speed, duration, space, effort, and limb and trunk extensions.

\section{Appendix 1}

Emotions in the Classroom (Smrtnik Vitulić and Prosen, 2016)

In the classroom, observe the emotions of the chosen child and the reactions to these emotions (of the other children and the teacher). In each part of the scheme, describe the characteristics of the observed emotions.

Observer's first name and surname:

Name of school, town:

Age of children:

Age and gender of the chosen child:

Number of children in the class:

\begin{tabular}{|l|l|l|l|l|}
\hline $\begin{array}{c}\text { Name of } \\
\text { emotion }\end{array}$ & $\begin{array}{c}\text { Situation } \\
\text { description }\end{array}$ & $\begin{array}{c}\text { a) Verbal expression } \\
\text { b) Non-verbal } \\
\text { expression }\end{array}$ & $\begin{array}{c}\text { Intensity of } \\
\text { expression } \\
(1=\text { very low ... } \\
5=\text { very high })\end{array}$ & $\begin{array}{c}\text { Reaction } \\
\text { of teacher/ } \\
\text { other } \\
\text { children }\end{array}$ \\
\hline & & & & \\
\end{tabular}

\section{References}

Bognar, L., \& Dubovicki, S. (2012). Emocije u nastavi. Croatian Journal of Education, 14(1), 135-153.

Bognar, L., \& Kragulj, S. (2010). Kvaliteta nastave na fakultetu. Život i škola, LVI(24), 169182. Damasio, A. R. (1998). Emotion in the perspective of an integrated nervous system. Brain Research Reviews 26(2-3), 83-86. https://doi.org/10.1016/S0165-0173(97)00064-7

Davidson, J. (2004). Embodied knowledge: Possibilities and constrains in arts education and curriculum. In L. Bresler (Ed.) Knowing Bodies, Moving Minds: Towards Embodied Teaching and Learning (pp. 197-211). Springer. https://doi.org/10.1007/978-1-4020-2023-0 13

Denham, S. A., Blair K. A., DeMudler, E., Levitas J., Sawayer, K., Auerbach-Major S., \& P. Queenan (2003). Preschool emotional competence: Pathway to social competence? Child 
Development, 74(1), 238-256. https://doi.org/10.1111/1467-8624.00533

Derryberry, D., \& Rothbart, M. K. (1988). Arousal, affect, and attention as components of temperament. Journal of Personality and Social Psychology, 55(6), 958-966. https://doi. org/10.1037//0022-3514.55.6.958

Dubovički, S. (2014). Attitudes of future teachers towards evaluation of university courses. Život i škola, $\operatorname{LX}(31), 126-137$.

Duclos, S. E., Laird, J. D., Schneider, E., Sexter, M., Stern, L., \& Van Leighten, O. (1989). Emotion specific effects of facial expressions and postures on emotional experience. Journal of Personality and Social Psychology, 57(1), 100-108. https://doi.org/10.1037/0022$\underline{3514.57 .1 .100}$

Eisenberg, N., Hofer, C., \& Vaughan, J. (2009). Effortful control and its socioemotional consequences. In J. J. Gross (Ed.), Handbook of emotion regulation (pp. 287-306). The Guilford Press.

Erikson, E. H. (1980, 2014). Identiteta in življenjski ciklus [Identity and the Life Cycle]. UMco d.d.

Feldenkrais, M. (1990). Awareness through movement. Harper Collins Publishers.

Fox, N. A., \& Calkins, S. D. (2003). The development of self-control of emotion: Intrinsic and extrinsic influences. Motivation and Emotion, 27(1), 7-26. https://doi.org/10.1023/A:1023622324898

Frith, C. D., \& Frith, U. (2007). Social cognition in humans. Current Biology, 17(16), 724732. https://doi.org/10.1016/j.cub.2007.05.068

Ekman, P., \& Davidson, R. J. (1994). The nature of emotion: Fundamental questions. Oxford University Press.

Fredrickson, B. (2008). Promoting positive affect. In M. Eid \& R. J. Larsen (Eds.), The science of subjective well-being (pp.449-468). The Guilford Press.

Geršak, V. (2016). Creative movement as a holistic teaching approach in primary school. (Doctoral dissertation). Ljubljana: Faculty of Education.

Geršak, V., \& Geršak G. (2016). A kinaesthetic approach to teaching electrical engineering. World Transactions on Engineering and Technology Education, 14(3), 366-373.

Griss, S. (2013). Everybody, stand up! The power of kinaesthetic teaching and learning. Independent Teacher 10. http://www.nais.org/Magazines-Newsletters/ITMagazine/Pages/ Everybody-Stand-Up.aspx.

Griss, S. (2013). The power of movement in teaching and learning. Education Week Teacher. http://nolenparkhouse.com/594/docs/The $\% 20$ Power\%20of $\% 20$ Movement $\% 20 \mathrm{in} \% 20$ Teaching\%20and\%20Learning.pdf

Harris, P. L. (1996). Children and Emotion: The Development of Psychological Understanding. Blackwell Publishers.

Harter, S., \& Whitesell, N. R. (1991). Developmental changes in children's understanding of single, multiple, and blended emotion concepts. In C. Saarni \& P. L. Harris (Eds.), Children's understanding of emotion: Cambridge studies in social and emotional development (pp. 81116). Cambridge University Press.

Hosotani, R., \& Imai-Matsumura, K. (2011). Emotional experience, expression, and regulation of high-quality Japanese elementary school teachers. Teaching and Teacher Education, 27(6), 1039-1048. https://doi.org/10.1016/j.tate.2011.03.010 
Kail, R. V., \& Cavanaugh, J. C. (2010). Human development - a life-span view. Wadsworth.

Kroflič, B. (2002). The effects of creative movement as a teaching method on children's creative thinking. Educating Able Children, 6(1), 6-13.

Laban, R. (1988). The Mastery of Movement (4th edition, revised by L. Ullman). Northcote House.

Lazarus, R. S. (1991). Emotion and Adaptation. Oxford University Press.

Lewinski, P., den Uyl, T. M., \& Butler, C. (2014). Automated facial coding: validation of basic emotions and FACS AUs in FaceReader. Journal of Neuroscience, Psychology, and Economics, 7(4), 227-236. https://doi.org/10.1037/npe0000028

Meyer, D. K., \& Turner, J. C. (2007). Scaffolding emotions in classroom. In P. A. Schutz, \& R. Pekrun (Eds.), Emotion in Education (pp. 243-258). Elsevier Inc. https://doi.org/10.1016/ B978-012372545-5/50015-0

Michell, J. (2009). The psychometricians fallacy: Too clever by half? British Journal of Mathematical and Statistical Psychology, 62, 41-55. https://doi.org/10.1348/000711007X243582

Minton, S. (2008). Using movement to teach academics: the mind and body as one entity. Rowman \& Littlefield Education.

Oatley, K., \& Jenkins, J. M. (1996). Understanding emotions. Blackwell Publishers.

Osgood-Campbell, E. (2015). Investigating the educational implications of embodied cognition: a model interdisciplinary inquiry in mind, brain, and education curricula. Mind, Brain, and Education, 9(1), 3-9. https://doi.org/10.1111/mbe.12063

Overby, L. (2014). Student reflections: the impact of dance integration. In Y. L. Overby, \& B. Lepczyk (Eds.), Dance: current selected research, vol. 8 (pp. 183-194). AMS Press, Inc.

Papalia, D. E., Wendkos Olds, S., \& Duskin Feldman R. (2009). A child's world: Infancy through adolescence.McGraw-Hill.

Prosen, S., \& Smrtnik Vitulić, H. (2018). Children's emotional expression in the preschool context. Early Child Development and Care, 188(12), 1675-1683. https://doi.org/10.1080 $\underline{103004430.2016 .1278367}$

Prosen, S., \& Smrtnik Vitulić, H. (2014). Different perspectives on emotion regulation and its efficiency. Psihologijske teme, 23(3), 389-405.

Prosen, S., Smrtnik Vitulić, H., \& Poljšak Škraban, O. (2013). Observing teachers' emotional expression in their interaction with students. The New Educational Review, 1(3), 75-85.

Saarni, C. (1999). The development of emotional competence. The Guilford Press.

Guinard, J.-X. (2000). Sensory and consumer smiley face testing with children (2016). Trends in Food Science \& Technology, 11(8), 273-283. https://doi.org/10.1016/S0924-2244(01)00015-2

Siegel, D. J. (1999). The Developing Mind. The Guilford Press.

Sutton, R. E. (2007). Teachers' anger, frustration and self-regulation. In P. A. Schutz \& R. Pekrun (Eds.), Emotion in Education (pp. 259-274). Elsevier Inc. https://doi.org/10.1016/ B978-012372545-5/50016-2

Suzić, N. (2008). Emocije i afektivni stilovi u nastavi. Pedagogijska istraživanja, 5(2), 153-163.

Thom, L. (2010). From simple line to expressive movement: The use of creative movement to enhance socio-emotional development in the preschool curriculum. American Journal of Dance Therapy, 32(2), 100-112. https://doi.org/10.1007/s10465-010-9090-2 
Thompson, R. A. (2011). Emotion and emotion regulation: Two sides of the developing coin. Emotion Review, 3(1), 53-61. https://doi.org/10.1177/1754073910380969

Thompson, R. A., \& Meyer, S. (2009). Socialization of emotion regulation in the family. In J. J. Gross (Ed.), Handbook of emotion regulation (pp. 249-268). The Guilford Press.

\author{
Simona Prosen \\ Faculty of Education \\ University of Ljubljana \\ Kardeljeva ploščad 16, 1000 Ljubljana, Slovenia \\ simona.prosen@pef.uni-lj.si \\ Vesna Geršak \\ Faculty of Education \\ University of Ljubljana \\ Kardeljeva ploščad 16, 1000 Ljubljana, Slovenia \\ vesna.gersak@pef.uni-lj.si
}

\title{
Gregor Geršak
}

Faculty of Electrical Engineering (FE)

University of Ljubljana

Tržaška c. 25, 1000 Ljubljana, Slovenia

gregor.gersak@fe.uni-lj.si

\section{Helena Smrtnik Vitulić}

Faculty of Education

University of Ljubljana

Kardeljeva ploščad 16, 1000 Ljubljana, Slovenia

helena.smrtnik@pef.uni-lj.si 


\section{Kreativni pokret u učionici kao unapređenje funkcioniranja učenika u različitim područjima}

\section{Sažetak}

Kreativni pokret predstavlja aktivan pristup učenju koji studentima omogućuje da kroz pokret i ples izraze i kreiraju različite obrazovne sadržaje. Predstavlja mogućnost integriranja umjetnosti i pokreta u proces učenja. U studijskoj godini 2015./16. provedeno je istraživanje, uključujući i učenike drugog razreda osnovne škole $(N=104)$ tijekom nastave Matematike (geometrije). Studijom se pokušalo utvrditi utvrditi kako je korištenje kreativnoga pokreta povezano s funkcioniranjem učenika u različitim područjima: kognitivnom, socijalnom, emocionalnom, tijelu/fizičkom. Te su veze uspostavljene usporedbom skupine učenika u kojoj je provedena nastava, integrirajući kreativni pokret (eksperimentalnu skupinu) s grupom učenika u kojoj nastava nije uključivala kreativni pokret (kontrolna skupina). Podaci su prikupljeni različitim mjernim instrumentima, dok je tjelesna aktivnost mjerena narukvicama BodyMedia Core. Rezultati, izmedu ostalog, pokazuju visoko zadovoljstvo nastavnim programom kod obje skupine učenika, ali veća potrošnja energije i dugoročno poznavanje geometrije u eksperimentalnoj grupi učenika poučavanih korištenjem kreativnoga pokreta.

Ključne riječi: emocije; geometrija; kreativni pokret; potrošnja energije; znanje 